ROCZNIKI NAUK PRAWNYCH

Volume XXVIII, number $4-2018$

Englis h v e r s i o n

DOI: http://dx.doi.org/10.18290/rnp.2018.28.4-4en

EWELINA KUMOR-JEZIERSKA

\title{
THE PARENTAL RIGHTS OF A PRISON SERVICE OFFICER - THE FATHER OF A CHILD
}

\section{INTRODUCTION}

The constitutional principle of protection and care for the family is addressed by the regulations of the labour law. Recently, the area of parental rights safeguarded by the Labour Code has undergone many significant changes. ${ }^{1}$ One of the chief goals of these changes was to simplify, unify and organise the system of parental leave, increase its flexibility-in a way allowing parents to better adapt the pattern of its use to their individual choices and needs, and increase the parental rights of fathers. ${ }^{2}$

Officers of the Prison Service [henceforth referred to as PS] remain in a public service relationship governed by the provisions of the Act of 9 April 2010 on the Prison Service. ${ }^{3}$ The provisions of the general labour law are applied only if they are invoked by express reference in this Act. Such reference is made in Article 165 PSA in respect of available parental rights. In line with this provision, a prison officer has special rights related to

EwElina Kumor-JeZIERSKA, PhD, is a research assistant at the Department of Labour Law and Social Policy, Faculty of Law and Administration of the Jagiellonian University; address: Grodzka 53, 31-001 Kraków, Poland; e-mail: ewelina.kumor-jezierska@uj.edu.pl; https://orcid.org/00000002-9733-7667.

${ }^{1}$ Act of 28 May 2013 amending the Labour Code Act and certain other laws, Journal of Laws item 675; Act of 24 July 2015 amending the Labour Code Act and certain other acts, Journal of Laws item 1220; Act of 26 June 1974-the Labour Code, Journal of Laws 2018, item 108 [henceforth quoted as LC].

${ }^{2}$ Reasons for the draft amending act, $7^{\text {th }}$ Sejm, Sejm Paper no. 3288, p. 11.

${ }^{3}$ Journal of Laws of 2017, item 631 [henceforth quoted as PSA]; see Judgement of the Supreme Administrative Court in Warszawa of 28 October 2008, file ref. no. I OSK 1721/07, LEX no. 499777. 
parenthood specified in the Labour Code, with the exception of Article $186^{7}$ LC, unless the provisions of the PSA provide otherwise.

The rights of a PS officer-the father of a child-in respect of leave related to the birth and upbringing of a child can be divided into autonomous, subsidiary and equivalent. Autonomous rights are those that are available only to the child's father (paternity leave); subsidiary rights are those available to the father when the child's mother does not exercise them (maternity leave); lastly, equivalent rights can be used by the child's father on equal terms with the mother (leave on the terms of maternity leave, parental leave, childcare leave). ${ }^{4}$ It should be noted that the child's parents can perform work in a variety of employment settings. Therefore, our analysis will concern the regulation of leave associated with parenthood in the situation where the child's mother and father have the status of PS officers, where the child's father is a PS officer and the child's mother is in an employment relationship or covered by social insurance in the event of illness or maternity, as set forth in the Act of 13 October 1998 on the social insurance system, ${ }^{5}$ under a title other than employment relationship, for example she is self-employed, ${ }^{6}$ or when the child's mother is not covered by any sickness insurance.

\section{PATERNITY LEAVE}

Paternity leave is an autonomous right of a PS officer and is non-obligatory. The right to such leave is in no way linked to maternity, parental or childcare leave of the mother of the child. A PS officer who is the father of a child acquires this right also when the child's mother does not have an employee status or insurance under a title other than employment or is not in a public service relationship. The right to paternity leave is reserved to a PS officer during his employment and is not conditional on the duration of his service, or the basis for appointment, that is, whether the service is preparatory or permanent (for an indefinite period of time). Paternity leave is an entitlement which can be exercised by a PS officer only in kind and no equivalent may be granted in its place.

\footnotetext{
${ }^{4}$ See M. Latos-Mıкowska, "Uprawnienia ojców związane z rodzicielstwem," in Aktualne zagadnienia prawa pracy i polityki socjalnej (zbiór studiów), ed. Bolesław M. Ćwiertniak (Sosnowiec: Oficyna Wydawnicza Humanitas, 2013), 2: 332.

${ }^{5}$ Journal of Laws of 2017, item 1778.

${ }^{6}$ For more on this, see P.W. WIĘCŁAW, "Uprawnienia związane z rodzicielstwem przysługujące osobom prowadzącym własną działalność gospodarczą, Monitor Prawa Pracy 1 (2018): 20ff.
} 
Moreover, the right to paternity leave may also be exercised by a PS officer whose child was born or adopted at a time when the father of the child was not in a service or employment relationship. Importantly, to be able to exercise this right he needs to be in a public service relationship. If a PS officer does not take paternity leave to which he is entitled while changing his job at a time when this entitlement is still valid, he has the right to use the paternity leave with a different employer until the child reaches the age of two.

The only person entitled to take paternity leave is the child's father, being her natural parent ${ }^{7}$ or an adoptive one. Paternity leave of two weeks is available to a PS officer who is a father raising a child, however, only until she reaches the age of 24 months. In the case of a PS officer who is a father raising a child he has adopted, he has the right to take paternity leave of two weeks at any time, however, not longer than for 24 months from the date when the decision on adoption becomes final and until the child turns seven, and in the case of a child whose compulsory education was postponed-10 years of age (Art. $1823 \mathrm{LC}$ in relation to Art. 165 PSA). The duration of this leave depends on the number of children born at one birth or adopted at the same time. After these periods have expired, paternity leave will no longer be granted. Similarly, this right does not apply if the father of the child has been deprived of his parental rights or is only the child's legal guardian or acts in capacity of a foster family, or in the period when the application for the adoption of the child is still being processed by the court. The condition for granting leave in both cases is the bringing up of the child, which is to be interpreted as actual care of the child. ${ }^{8}$ Upbringing involves concern for the child's physical and spiritual development and preparing it for work for the good of society, according to her talents and abilities. ${ }^{9}$

Paternity leave is optional. The condition for this is that the entitled person submits a written request not later than 7 days before the start of the leave. Paternity leave may be taken once or in two parts, none of which lasting shorter than a week. One week of a paternity leave corresponds to

\footnotetext{
${ }^{7}$ The father of the child is a man who is subject to a presumption of paternity (Art. 62 FGC) or whose paternity has been established by way of recognition or by a court decision (Art. 72 para. 1 FGC).

${ }^{8}$ A. SовСZyк, "Komentarz do art. 1823," in Kodeks pracy. Komentarz, Legalis 2017/el., Proposition 2 .

${ }^{9}$ See B. BuRY, "Prawo ojca dziecka niebędącego pracownikiem do realizacji uprawnień związanych z urlopem macierzyńskim,” Monitor Prawa Pracy 5, no. 5 (2016): 246.
} 
7 calendar days (Art. $1831 \S 3$ LC in relation with Article $1831 \S 1$ PSA in relation to Article 165 PSA).

The PSA does not provide any regulations concerning formal conditions to be fulfilled when a paternity leave is applied for. Nonetheless, such formal requirements are provided for by $\S 21$ of the regulation of the Minister of Family, Labour and Social Policy of 8 December 2015 concerning applications related to the parental rights of employees and the documents accompanying such applications. ${ }^{10}$ Due to the general reference used in Article 165 PSA to the direct application of the provisions concerning individual parental rights specified in the Labour Code and the lack of specific PSA regulations in this regard, the formal requirements related to this application are also used for applications submitted by prison service officers. Such an application should include the name and surname of the PS officer who applies for paternity leave, the period for which paternity leave or its part is to be granted. A prison service officer who is a natural father to a child whom he raises is to include in the application for paternity leave or its part an abbreviated copy of the birth certificate of the child(ren) or the foreign birth certificate of the child(ren) or copies of these documents and his declaration whether he has taken paternity leave or its part. However, in the case when the application concerns the granting of paternity leave or its part for an adopted child, a PS officer is to attach a copy of the legally binding court decision on the adoption of that child, his statement whether he has taken paternity leave or its part, and a copy of the legally binding decision on the postponement of compulsory education if the application concerns a child in respect whom such a decision was taken. The employer is obliged to grant paternity leave to a PS officer. A refusal to grant it is justified only if the entitled person has already used it with a previous employer. Paternity leave may be interrupted for the duration of the child's hospitalisation (Art. 1823 $\S 3 \mathrm{LC}$ in relation to Art. $181 \mathrm{LC}$ in relation to Art. 165 PSA). In such a case, the remainder of the leave can be used at a later time by the father (PS officer) raising a child, when the child leaves the hospital. However, it should be noted that paternity leave is not interrupted ex lege for the duration of the child's hospitalisation, but its interruption is at the discretion of the applicant.

\footnotetext{
${ }^{10}$ Journal of Laws item 2243 [henceforth referred to as Regulation 2015].
} 


\section{MATERNITY LEAVE}

As of 2 January 2016, a broader catalogue was introduced for cases in which the child's father may "take over" a part of maternity leave from a female PS employee or officer or the child's mother covered by social insurance in the event of illness and maternity, as provided for in the Act on the social insurance system, for a reason other than the employment relationship. It should be noted that the insured mother of the child does not take maternity leave because her status is not one of an employee, but only claims maternity allowance for the period corresponding to maternity leave. An important amendment is also the possibility of using, in specific situations, maternity leave by a PS officer even when the child's mother is not covered by or is not eligible for social insurance in case of illness or maternity. The right of a PS officer - the father - to take part of maternity leave is subsidiary because he may use it only if it has not been used by the child's mother. The right to a part of the maternity leave is granted only to the father raising a child thus exercising the actual custody of the child and is a father pursuant to provisions of the FGC.

A PS officer who is a father raising a child, pursuant to the LC and the PSA, is entitled to take the remaining portion of maternity leave in several cases. The first is a situation where a female PS employee or officer has used at least 14 weeks of this leave after the birth and surrenders the remainder for the benefit of the father (Article $180 \S 4 \mathrm{LC}$ in relation to Article 165 LC) or in the event when the insured - the child's mother-waives her entitlement to maternity allowance after she has used this allowance for at least 14 weeks after the birth (Art. $180 \S 5$ LC in relation to Art. 165 PSA).

In order for the remaining part of maternity leave to be "taken over" by the male PS officer, it is necessary to synchronize the written applications of the officer and the child's mother, who are obliged to submit them to their employer. The request submitted by a PS officer who is a father raising a child requires to be made in written form not later than 14 days before the start of the part of the leave. Its content should specify:

-the applicant's full name

- the child's (children's) full name and date of birth in respect of whom the remainder of the maternity leave is to be granted

- the applicant's statement on the duration of maternity leave or the period of collecting maternity allowance for the duration corresponding to the period of the portion of maternity leave taken before the birth 
- an indication of the period for which on the remainder of maternity leave is to be granted.

The applicant is obliged to attach to the application an abbreviated copy of the birth certificate of the child(ren) or a foreign birth certificate of the child(ren) or copies of these documents. Depending on the situation, when the remaining part of the maternity leave is surrendered by a female PS employee or officer, the applicant attaches a statement on her intention to give up the remainder of the maternity leave. However, if the child's mother is not a PS employee or officer but a person covered by sickness insurance under a title other than employee relationship and claims maternity allowance, the applicant attaches a statement of the insured mother on her intention to surrender her maternity allowance for the duration corresponding to the period of the remaining part of the maternity leave ( $\$ 8$ of Regulation 2015). On the other hand, the child's mother, who has the status of a PS employee or officer, submits a written request to her employer to surrender part of her maternity leave no later than 7 days before commencing work. She is to attach a copy of the application for the remaining portion of the maternity leave submitted by a PS officer - the father raising the child ( $\$ 6$ of Regulation 2015).

The other cases where a PS officer who is a father raising a child has the right to take part of the maternity leave concern special situations. It should also be added that in these cases the father of the child is not the only eligible person to use part of maternity leave. This right is also available to a PS employee or officer who may be regarded as a members of the immediate family. A prison service officer-a father raising a child, pursuant to the Labour Code and the Prison Service Act, may use part of the maternity leave when:

- a female PS employee (or officer) - the mother of a child holding a certificate of incapacity for independent existence, having used at least 8 weeks of maternity leave after the birth, surrenders the remainder of this leave (Art. $180 \S 6 \mathrm{LC}$ in relation to Art. 165 PSA) or

-when an insured person - the mother of the child holding a certificate of incapacity to live independently decides not to claim the remainder of her maternity allowance after she has used it for at least 8 weeks after the birth (Art. 180 \& 7 LC in relation with Art. 165 PSA) or

-if the child's mother is unable to provide personal care for the child, holds a certificate of incapacity for independent living but is not covered by social insurance in case of illness and maternity, or does not have the right to such insurance. In this situation, the male PS officer-the father raising the 
child - may immediately "take over" the part of maternity leave starting on the next day after the inability to exist independently arose (Art. $180 § 15$ LC in relation to Art. 165 PSA). ${ }^{11}$

As in the previous case, for the remaining part of maternity leave to be "taken over" at all by a male PS officer, it is necessary to synchronise the written applications of the officer and the child's mother, who are obliged to submit them to their employer. It should be remembered that the child's mother can only waive maternity leave if its continuity is ensured by an eligible person. Therefore, the mother must submit to her employer an application for resignation from the maternity leave not later than 7 days before starting work, while the father of the child is obliged to submit an application to the employer for taking the remainder of the maternity leave not later than 14 days before starting to use the leave.

A female PS officer-a father raising a child-has the right to take the part of the maternity leave which the mother of the child has not used in two other special cases: abandonment of the child or its death. If the child is abandoned by the mother, the right of the male PS officer-the father raising the child - to use a part of the maternity leave depends on the mother's status. In a situation when the child's mother is entitled to take maternity leave, it is a PS officer-the father raising the child-has the right to a part of the maternity leave, but only after the child's mother has used 8 weeks of maternity leave after giving birth. Similarly, when a mother abandons her child while claiming her maternity allowance for a period corresponding to that of this leave - the entitled father of the child has a right to use the part of the maternity leave starting after the date when the child was abandoned, but not earlier than after the insured person-the mother-has claimed the maternity allowance for at least 8 weeks after the childbirth (Art. $180 \S 13$ LC in relation to Art. 165 PSA). However, if the child's mother is not covered by insurance in case of illness and maternity or did not have a title to it, a male PS officer-the father raising the child has the right to the part of the maternity leave falling immediately after the date when the child was abandoned (Art. $180 \S 15$ LC in relation with Art. 165 PSA).

On the other hand, in the event that a child's mother dies during maternity leave or during the period when she claims maternity allowance for the period corresponding to the period of such leave or that the child's mother

\footnotetext{
${ }^{11}$ For more on this, see E. KUMOR-JeZIERSKA, "Urlop macierzyński funkcjonariuszki Służby Więziennej,” Roczniki Nauk Prawnych 28, no. 1 (2018): 29-51, doi: http://dx.doi.org/10.18290/ rnp.2018.28.1-3.
} 
dies not covered by social insurance in the event of illness and maternity, or not having a title to be covered by such insurance, a male PS officer-the father raising the child-is entitled to the part of the maternity leave starting after the date of the child's mother's death (Art. $180 \S 12$ and $\S 15$ LC in relation to Art. 1656 PSA).

A male PS officer, the father raising a child, is entitled to take a portion of the maternity leave in a situation where the child's mother, due to her state of health preventing her from taking personal care of the child, decides to discontinue it. This situation is possible only when the mother is in a hospital or another medical facility providing both in-patient and 24-hour health care services. The father can use this right if the mother took at least eight weeks of maternity leave after the child birth and, in the case of an insured mother, the woman claimed her maternity allowance for at least eight weeks after the childbirth. The right of a PS officer to use a part of maternity leave concerns only the period in which the woman entitled to maternity leave or only a maternity allowance-the child's mother is in hospital or another medical facility mentioned above (Art. $180 \S 10$ and $\S 11$ LC in relation to Art. 165 PSA). The legislator has not specified the time limit within which the child's father may submit an application for a part of the maternity leave. It should be assumed that the application should be submitted immediately, so that the continuity of maternity leave is maintained, whereas the employer is obliged to grant maternity leave within a specified period of time. The formal conditions are laid down in the Regulation ( $\$ 9$ and $\S 10$ of Regulation 2015). If the child's mother leaves hospital or other medical facility, the child's father should discontinue this leave.

It should also be added that a PS officer-a father raising a child can make use of maternity leave also when the child's mother was not entitled to maternity leave on the day of childbirth or she had no right to be covered by social insurance in case of illness and maternity, but took up employment in the amount not lower than half-time. The mother of a child should take up employment during the period in which she is entitled to maternity leave, for example within 20 weeks from the giving birth to one child at one birth. ${ }^{12}$ In such a case, the PS officer - the father raising the child - is entitled to a part of the maternity leave during the period of the child's mother's employment

\footnotetext{
${ }^{12}$ See IDEM, "Komentarz do rozporządzenia z dnia 8 grudnia 2015 r. w sprawie wniosków dotyczących uprawnień pracowników związanych z rodzicielstwem oraz dokumentów dołączanych do takich wniosków," in Akty wykonawcze prawa pracy. Komentarz, ed. K.W. Baran (Warszawa: Wolters Kluwer Polska, 2016), 256.
} 
starting on the day when she takes up employment until the leave expires. If in the period in which the child's mother is entitled to maternity leave her employment ceases - a PS officer - the father raising the child will lose the right to a part of the maternity leave.

\section{LEAVE ON THE TERMS OF MATERNITY LEAVE}

The right to leave on the terms of maternity leave is one of the entitlements which the father of the child has on equal terms with the child's mother. This is leave which can be used by a PS officer who has accepted a child for upbringing and applied to the guardianship court for institution of proceedings concerning the adoption of the child or has accepted a child as a foster parent, but not as a professional foster family. Its duration depends on the number of children simultaneously accepted for upbringing and their age. ${ }^{13}$ Adoptive/foster parents of a child who are in a PS relationship or that of employment, or when either is covered by sickness insurance under a title other than a employment relationship (e.g. contracts of mandate), they may share this leave on the same terms as those provided for maternity leave for natural parents (Art. $183 \S 2$ in relation to Art. $180 \S \S 4-17$ LC in relation to Art. 165 PSA). The child's father, who is an employee of the Prison Service can be the first to take leave on the terms of maternity leave, as in this case there is no statutory obligation for an employee or a female PS employee or officer - the mother of the child or the child's insured mother-to use at least the first 14 weeks of the leave. ${ }^{14}$ Thus, the father of the child, having used at least 14 weeks' leave, can surrender it and return to service, while the remainder of the leave can be taken by the adoptive/foster mother on the terms of maternity leave, who is either a PS employee or officer; or for a period corresponding to the period remaining until the end of leave on the

\footnotetext{
${ }^{13} 20$ weeks if one child is accepted; 31 weeks if two children are accepted simultaneously; 33 weeks in the case of simultaneous admission of three children; 35 weeks if four children are accepted simultaneously; 37 weeks in the case of simultaneous admission of five or more children, but not longer than until one child reaches the age of seven, and in the case of a child for whose compulsory education has been deferred, not longer than until the child reaches the age of ten. On the other hand, if an employee has accepted a child up to the age of 7, while in the case of a child whose compulsory schooling has been deferred until the age of 10, the employee is entitled to 9 weeks of leave on the terms of maternity leave.

${ }^{14}$ See also M. WŁodarczyK, "Komentarz do art. 183," in Kodeks pracy. Komentarz, ed. K.W. Baran (Warszawa: Wolters Kluwer Polska, LEX 2016 el.), Proposition 3.
} 
terms of maternity leave, personal custody of the child will be provided by an insured woman (adoptive/foster mother), who will interrupt her gainful activity in order to take care of the child. The case will be similar when a PS officer-the father of the child starts taking leave on the terms of maternity leave and one of the special circumstances occurs under which it will be possible to surrender or interrupt such leave (i.e. he presents a certificate of inability to exist independently, is hospitalized, abandons the child, or dies during the leave on the terms of maternity leave). Then, pursuant to the Labour Code and the Prison Service Act, the persons entitled to "take over" a portion of maternity leave will be an adoptive/foster mother-raising the child and being in an employment or public service relationship with the Prison Service, or a PS employee who is a member of the closest family. Apart from that, the custody of the child can be taken over by the insured adoptive/foster mother or an insured person-another member of the closest family who, in order to provide this custody, has interrupted his or her gainful activity. In the case of adoptive/foster parents, it is doubtful whether the father of the child who is the first to take leave on the terms of maternity leave has the right to surrender it or interrupt it immediately, or whether he has to wait until at least eight weeks have elapsed as is the case with the biological mother of the child who has taken maternity leave on the day of childbirth. In this case, there is no post-partum period for the mother of the child. Consequently, a male PS officer who takes leave on the terms of maternity leave may waive this right to the remainder of this leave not earlier than after taking at least 8 weeks of it because provision of child care by at least one parent or another member of the immediate family should be of priority. ${ }^{15}$

\section{PARENTAL LEAVE}

Pursuant to the Labour Code and the Prison Service Act, the right to parental leave is vested in both natural parents and both adoptive/foster parents who are PS employees or officers. Parental leave is optional, so it has to be applied for. Parental leave may be granted directly after the maternity leave has been used or maternity allowance has been claimed for the period corresponding to the period of maternity leave, once or in parts (maximum 4), not later than the end of the calendar year in which the child turns 6 . No part of

\footnotetext{
${ }^{15}$ See also KUMOR-JEZIERSKA, Komentarz do rozporzadzenia, 233-34, 242.
} 
parental leave may be shorter than eight weeks, with certain exceptions specified in Article 1821c $\S 4$ LC. ${ }^{16}$ The main idea of parental leave is to enable parents to exercise personal care of a child in the stages of her life. ${ }^{17}$ However, as of 2 January 2016, following the entry into force of the Act of 24 July 2015 amending the Labour Code and certain other acts, it is possible to take part in parental leave even after a few years' break. Pursuant to Article $1821 \mathrm{c} \S 3 \mathrm{LC}$, parental leave of up to 16 weeks may be granted for a period not immediately following the previous part of the leave or not immediately following the period when maternity allowance was used for the period during which part of the leave was taken, e.g. when the child is of preschool age. Both parents are entitled to full-time parental leave together. Eligible parents have the right to choose how they will use this leave. Either of the eligible parents can use the whole of parental leave, or they can share it. It should also be noted that a PS officer is not obliged to use the full amount of parental leave, they may use it only in part or surrender it. Parents can also take parental leave at the same time if they are both employees or officers of the Prison Service or if one of them is an officer and the other an employee of the PS. On the other hand, if one parent is a PS employee or officer, and the other parent is covered by social insurance in the event of illness and maternity, for example, under a contract of mandate, then both parents may benefit in parallel: one from parental leave and the other from the allowance. However, the total amount of leave and the period of claiming the allowance may not exceed the amount of leave indicated in Article 1821a $\S 1$ points 1 and 2 of the Labour Code. A male PS officer is entitled to parental leave; however, it can be granted on condition that maternity leave or allowance has been used earlier by the eligible persons for the period corresponding to the length of the leave. However, the right to parental leave may be exercised by a person other than the beneficiary of maternity leave or allowance. Moreover, the right to parental leave may be exercised by a person who is a PS employee or officer on the day when the entitlement arises but was not a PS

\footnotetext{
${ }^{16}$ No part of parental leave may be shorter than 8 weeks, except for: the first one, which in the case of having one baby at one birth may not be shorter than 6 weeks, acceptance of a child aged up to 7 for bringing up, and in the case of a child aged up to 10 years in respect of whom a decision has been made to postpone her compulsory education, may not be shorter than 3 weeks, and in a situation where the remainder of the leave is shorter than 8 weeks (Art. 1821c $\S 4 \mathrm{LC}$ in relation to Art. $1791 \S 2$ LC in relation to Art. 165 PSA).

${ }^{17}$ See ŚwiąTKowsKi, Kodeks pracy. Komentarz, $5^{\text {th }}$ ed., Legalis 2016/el., commentary for Art. $1821 \mathrm{a}$.
} 
employee or officer, or covered by insurance earlier. ${ }^{18}$ It should also be said that parental leave may be requested in two ways. In the first case, in the case of biological parents, parental leave is reserved only for the mother, who within 21 days after the childbirth can submit a written request for a parental leave in the full amount under Art. 1821a $\S 1$ LC immediately after finishing the maternity leave (Art. $1791 \S 1$ LC). The mother of a child having the status of an employee or officer of the Prison Service, who has applied to the employer for granting her parental leave in this manner, has the right to change her decision and share parental leave with the father of the child who has the status of a PS officer, in accordance with the principles set out in Article 1821c $\S \S 2$ and $\S$ LC. Parental leave in this manner to the child's father may not be used in a period which is does not immediately follow the previous part of that leave or the maternity allowance period for the period corresponding to the part of that leave. These provisions are also applied accordingly to parental leave for parents applying for child adoption or being a foster family, except for professional foster families (Art. 1824 LC). A correctly submitted and documented application is binding on the employer.

The second method does not depend on the applicant's gender and the entitled person can submit an application for parental leave not later than 21 days before the beginning of the leave (Art. 1821c $\$ 1$ LC). A male PS officer may waive parental leave at any time with the consent of the employing entity and return to service (Art. $1821 \mathrm{~d} \S 3 \mathrm{LC}$ in relation to Art. 165 PSA). The employer is not obliged to give consent to an earlier return of a male PS officer to service and in such a case the officer remains on parental leave until the end of the period for which the leave was granted.

In the Labour Code, the legislator introduced the possibility of combining parental leave with the performance of work for an employer granting such leave in the amount not exceeding half of full-time employment. In this case, parental leave is granted for the remaining part of the work time (Art. 1821e $\S 1$ LC). An employee may combine the use of parental leave with performing work for an employer granting such leave in the amount not exceeding half of full-time employment. Therefore, a worker may, during parental leave, perform work at half of the full time or less, for example quarter time. The employer is obliged to accept the employee's application unless it is

\footnotetext{
${ }^{18}$ See also A. SoвCZYK, "Komentarz do art. 182 1a," in Kodeks pracy. Komentarz, Legalis 2017/el., Proposition 2.
} 
impossible to do so due to the organisation of work or the type of work performed. The reason for refusal must be notified in writing to the employee (Art. 1821e $\S 2$ LC). If an employee combines parental leave with the performance of work for the employer granting the leave, the length of parental leave is extended proportionally to the length of work performed by the employee during the leave or its part, however, not longer than 64 weeks when giving birth to one baby at one birth (or accepting a child for upbringing) and 68 weeks in other cases (Art. 1821f $\S 1$ LC). In Article 1821f $\S 2-5$ and $\S 7 \mathrm{LC}$, the legislator defined the algorithm used to calculate the period by which parental leave is extended. The Prison Service Act does not explicitly exclude the use of the said regulation, as opposed to the possibility of working reduced hours during the parental leave referred to in Article 1867 LC. This raises doubts as to whether this institution can be applied to officers of the Prison Service. The PS Act has no regulations which would decrease the amount of service time for PS officers; nor does it have provisions on the calculation of remuneration proportional to the amount of service, therefore it seems that this provision cannot be applied to PS officers. We should bear in mind that in the case of an employee, the possibility of taking parental leave and combining it with work for the employer granting such leave does not result in the creation of a new employment relationship, but rather makes it possible to continue the existing employment only in a limited amount. ${ }^{19}$

\section{CHILDCARE LEAVE}

A male PS officer who has been employed for at least 6 months is eligible for parental leave to take personal care of a child. This is another of the equivalent rights vested in the child's father, which he exercise on equal terms with the child's mother. It does not matter whether the child's mother has the status of a PS employee or officer, or whether she is a person covered by sickness and maternity insurance for reasons other than employment, or whether she is a person not covered by this insurance. Moreover, acquisition of the right to parental leave and its use does not depend on the prior utilisation of maternity leave, paternity leave or parental leave by a PS

\footnotetext{
${ }^{19}$ P. SEKULSKI, "Dopuszczalność zatrudnienia w okresie wykorzystania urlopów związanych z rodzicielstwem," in Uprawnienia pracowników zwiąane z rodzicielstwem $w$ świetle przepisów prawa pracy i ubezpieczeń społecznych, ed. J. Czerniak-Swędzioł (Warszawa: Wolters Kluwer Polska, 2016): 143.
} 
officer-the child's father. All periods of employment are included in the six-month period of employment. Therefore, these are periods of employment with both the previous and the current employer, regardless of the breaks between them or the way in which they cease. This refers to work performed by a PS officer not only on the basis of a public service relationship, that is, appointment for preparatory service and permanent service, but also on the basis of work performed before employment in the service on the basis of a employment relationship. ${ }^{20}$

Parental leave is granted for a period not exceeding the end of the calendar year in which the child turns 6. Parental leave is granted in up to five parts, which need not be taken directly in succession and they need not be equal. The number of parts of parental leave is granted on the basis of the number of submitted applications for parental leave. The number of the five parts of childcare leave that may be used by a PS officer is reduced when the applicant decides to take parental leave later than directly after the used part of parental leave, that is the part which is no longer than 16 weeks, whichpursuant to Article $1821 \mathrm{c} \S 1 \mathrm{LC}$-may be used until the end of the calendar year in which the child attains the age of six.

The amount of parental leave is up to 36 months, but during this period both parents or legal guardians of a child are entitled to one month of leave at their sole disposal. This right cannot be transferred to the other parent or guardian, which means that if the leave is not taken, it will be correspondingly shorter. ${ }^{21}$ Pursuant to Article $186 \S 3$ LC in relation to Article 165 PSA, if the child requires personal care of a PS officer on account of disability, the fact or degree of which is documented, apart from the basic amount of such leave, childcare leave may be granted of up to 36 months (as if it were an "additional" childcare leave), but for a period not longer when the child reaches the age of 18 .

If the child's parents have the status of PS employees or officers, they may be on childcare leave simultaneously, and its combined duration is not limited in time. However, the total duration of childcare leave may not

\footnotetext{
${ }^{20}$ Court of Appeal in Białystok included even the period of receiving unemployment benefit (Judgement of 18 June 1998, file ref. no. III AUa 296/98, Legalis) in the period of employment.

${ }^{21}$ The legislator provided for exceptions when the child's parent has the right to childcare leave of up to 36 months (this rule applies to both basic childcare leave and leave due to the child's disability), namely when: the other parent of the child is dead (Art. $186 \S 9$ point 1 LC); the other parent of the child has no parental authority (Art. $186 \S 9$ point 2); the other parent's authority has been revoked or such authority has been limited or suspended (Art. $186 \S 9$ point 3 ). The same rule applies if the child is in the care of a single guardian (Art. $186 \S 10$ ).
} 
exceed its maximum duration. This means that parents or guardians can look after their child simultaneously as part of childcare leave, for up to 18 months, and in the case of a disabled child for up to 36 months.

A written request for granting childcare leave is submitted by a PS officer to the employer not later than 21 days before its commencement. The service provider is obliged to accept a correctly submitted application. The employer's obligation to grant childcare leave arises when the employee presents a statement or certificate confirming his/her right existing at the time of starting the leave. ${ }^{22}$ If an application for childcare leave is submitted without observing this time limit, the employer grants parental leave no later than of 21 days from the date of submitting the application (Article $186 \S 71$ LC in relation to Art. 165 PSA). Furthermore, the applicant may, no later than 7 days before the start of the leave, withdraw the application by submitting a relevant statement (Art. $186 \S 7$ LC in relation to Art. 165 PSA). The legislator also provides for situations where an entitled person taking childcare leave may surrender it. With the employer's consent, he or she may do so at any time; if no consent is given, after a prior notification given to the employer-not later than 30 days before the date of the intended commencement of service (Art. 1863 LC in relation to Art. 165 PSA). The provisions of both the PSA and the LC do not specify the content of the waiver notice or the content of the notice of withdrawal of the application for granting parental leave.

If a PS officer uses childcare leave while in preparatory service, the period of preparatory service is extended by the period of the parental leave (Art. 42 para. 5 PSA). It should also be mentioned that the service record required to occupy a particular official position is not included in childcare leave (Art. 47 para. 2 PSA).

We also need to pay attention to Article 1862 LC, pursuant to which an employee has the right to take up paid employment during childcare leave with the existing or a different employer or other activity, and education or training if this does not exclude the possibility of taking personal care of a child. ${ }^{23}$ The essence of personal childcare is that, for a person using child-

\footnotetext{
22 Judgement of the Supreme Court of 24 September 2015, file ref. no. II PK 274/14, LEX no. 1962475.

${ }^{23}$ See A. ZAWIŚLAK, "Dopuszczalność pracy u innego pracodawcy w trakcie urlopu wychowawczego — na tle wybranych pragmatyk służbowych," Monitor Prawa Pracy 9 (2017): 467; B. Cudowski, Dodatkowe zatrudnienie (Warszawa: Wolters Kluwer Polska, 2007), 120; A. DuBOwnIK, "Dodatkowe zatrudnianie i inne zajęcia pracowników sfery publicznej," Praca i Zabezpieczenie Spoteczne 10 (2005): 17-18.
} 
care leave it is a fundamental, permanent and daily duty to provide the child with the essential means of security, subsistence, development and education, to the extent that simultaneous provision of care by others is superfluous. In the daily account of the care provided, there may exist interruptions in the child's contact with the parent (shopping, medical appointments, seeing grandparents). However, such situations cannot be compared with interruptions resulting from employment. ${ }^{24}$ The Prison Service Act contains a special regulation in relation to the provisions of the Labour Code. In the case of PS officers taking up gainful employment the legislator imposes restrictions. A PS officer may not undertake a gainful occupation outside the service without the superior's permission (Art. $160 \S 1$ PSA). We should conclude that during the period of childcare leave, a PS officer may not take up paid employment without the prior consent of his/her superior, as they are still in a public service relationship. It should be noted that under the provisions of the Labour Code no obligation transpires to inform the employer of the intention to work for another employer or to obtain consent in this respect. However, in the case of officers, the purpose of prior approval for taking up employment outside service is to ensure the impartiality of PS officers in their performance, and to prevent situations in which the taking up of an additional job is at conflict with the principle of "commitment to service." ${ }^{25}$ The superior may permit an officer to take up gainful employment outside the service, but three conditions must be met. This job must not:

-interfere with the officer's performance of service duties

as specified by the Prison Service Act

-blemish the prestige of the service

-undermine public confidence in the impartiality of the officer.

If any of the above conditions is not satisfied, not consent will be granted. ${ }^{26}$ Additionally, the Regulation of the Minister of Justice of 18 June

\footnotetext{
${ }^{24}$ Judgement of the Supreme Administrative Court in Warszawa of 25 March 2011, file ref. no. I OSK 2066/10, LEX no. 1079748.

${ }^{25}$ T. KuCZYŃSKi, E. MAZURCZAK-JASiŃSKA, and J. STElina, "Stosunek służbowy," in System Prawa Administracyjnego, ed. R. Hauser, Z. Niewiadomski, and A. Wróbel (Warszawa: Wydawnictwo C.H. Beck, 2011), 422

${ }^{26}$ If a PS officer violates any of the conditions after permission has been granted to take up gainful occupation, the supervisor will withdraw the permission. If - after permission has been granted-circumstances justifying a refusal to grant permission have come to light, the supervisor is to immediately revoke - in the written form - the permission granted previously. Withdrawal of permission does require a justification.
} 
2010 on granting permits to officers seeking gainful employment outside the Prison Service ${ }^{27}$ specifies:

- the procedure for granting permission for paid employment outside the service

- data which should be included in a PS officer's application for permission to take up paid employment outside the service

- the manner and time limit within which an officer is to be notified of the grant, refusal or revocation of permission.

The legislator does not specify in the Prison Service Act or in the Regulation a catalogue of gainful employment outside the service that an officer may undertake; nor is this term defined. Therefore, this concept includes activities performed by an officer on the basis of an employment relationship, a civil-law relationship, as well as activities performed as part of individual business operation. ${ }^{28}$ In addition, officers and employees may not engage in any activity that undermines the authority of the Prison Service or in which information of interest to the Service is used for non-service purposes. Moreover, it is forbidden for officers and employees to engage in contacts other than those resulting from official duties with persons deprived of their liberty, or to provide unauthorized persons with information about persons deprived of their liberty, even after their release. ${ }^{29}$ The PSA does not ban the involvement of Prison Service officer in training and education. The question also arises whether a PS officer can take up paid employment with their own official service provider during the period of childcare leave. Any involvement of PS officers during childcare leave, whether to be educated, trained or to work for the existing employer, must be assessed from the angle of "the possibility of ensuring personal care to a child" and the provisions of the PSA. Inability to provide childcare can take place either because the activities undertaken are time-consuming or because of the inconvenience of an activity, even not time-consuming (e.g. one related to the workplace or to recreation), that makes personal childcare illusory. ${ }^{30}$

\footnotetext{
${ }^{27}$ Journal of Laws No. 122, item 834.

${ }^{28}$ M. KaCzocha, "Służba Więzienna," in Komentarz, ed. M. Mazuryk and M. Zoń, LEX 2013/el. 396.

${ }^{29}$ See E. KUMOR-JEZIERSKA, "Dokumentacja w stosunkach zatrudnienia nawiązanych na podstawie ustawy o służbie wewnętrznej," in Dokumenty w zatrudnieniu na podstawie pragmatyk stużbowych. Wzory i komentarze, ed. K.W. Baran (Warszawa: Wolters Kluwer Polska, 2015), 744.

${ }^{30}$ See A. SOBCZYK and P. KoRUs, "Aktywność prywatna i zarobkowa pracownika a urlop wychowawczy," Monitor Prawa Pracy 1 (2014): 24.
} 
An employee, pursuant to Article 1867 LC, who is entitled to childcare leave, may also take advantage of another form of taking care of and bringing up a child, that is, a reduced working time, no more than half-time. It is an institution which permits work to be combined with duties related to raising children. It makes it possible to continue work and professional development and to retain the source of income for the parent, as low as they may be. ${ }^{31}$ Such an entitlement is not available to PS officers. This exclusion follows directly from Article 165 PSA.

\section{PROTECTION OF THE PUBLIC SERVICE RELATIONSHIP}

During maternity leave, leave on the terms of maternity leave, paternity leave or parental leave-pursuant to Article 108 PSA - prison service officers enjoy special protection of their service relationship. This means that during that period they cannot be dismissed from service or their service relationship may not be terminated. The legislator provides for a few exceptions to this rule. The first is the situation when a PS officer submits a written withdrawal from service (Art. 96 para. 1 point 2 PSA); the second situation is where an officer is appointed for a different public service (Art. 96 para. 2 point 2 PSA). The other cases concern: liquidation of an organisational unit or its reorganisation combined with a reduction in the workforce if the transfer of a PS officer to another organisational unit or to a lower service position is not possible (Art. 96 para. 2 point 4 PSA); a final court ruling awarding a disciplinary measure resulting in expulsion from service; conviction by a final judgement to imprisonment if the enforcement of this punishment has not been suspended conditionally; intentional indictable offence or an intentional fiscal offence prosecuted by public indictment or an intentional fiscal offence; a final court ruling imposing a penal measure of deprivation of public rights or a penal measure prohibiting the service as a PS officer; absence from service for a period exceeding 3 months due to temporary arrest; renunciation of Polish citizenship; abandonment of service; death; or confirmation of the disappearance of an officer (Art. 97 para. 1 points 2-10 PSA).

\footnotetext{
${ }^{31}$ M. MĘDRALA, "Wpływ okresu korzystania przez pracownika z obniżonego wymiaru czasu na wymiar urlopu wychowawczego," Monitor Prawa Pracy 10 (2017): 511.
} 
The legislator does not provided for special protection of a PS officer's service relationship during parental leave. An officer dismissed from service during a period of parental leave on account of the liquidation of the organisational unit or its reorganisation combined with a reduction in the workforce-if it is not possible to transfer the officer to another organisational unit or to a lower official position - until the end of the period for which the leave was granted is entitled to:

— cash benefits, paid in accordance with the rules governing the payment of parental allowance

-other benefits provided for employees dismissed from work during parental leave for reasons not related to employees.

\section{CONCLUSION}

The Prison Service Act provides for a less favourable solution in comparison with that provided under the Labour Code with regard to protection of the public service relationship when a PS officer is on childcare leave. Moreover, a PS officer may not-without the consent of the employing institution - take up additional employment during childcare leave, despite the fact that Art. 1862 of the Labour Code leaves this matter to the discretion of the employee. It also seems less advantageous to exclude the institution permitting the service to be performed on a part-time basis in combination with child raising. A female PS officer would have the opportunity to pursue her career and to provide direct personal childcare. The welcome solution is that PS officers-women and men-can exercise parental rights, in principle, on the same terms as employees of both sexes. Similar solutions were also established by the legislator regarding the amount of remuneration, where the same rules were adopted for determining the percentage of remuneration during the period when PS officers took leave on account of birth and childcare, as in the case of employees. The move towards increased rights of the child's father should be evaluated as the most appropriate direction for changes, as it gives the other parent the opportunity to participate in the child's education and care. 


\section{BIBLIOGRAPHY}

\section{NORMATIVE ACTS}

Ustawa z dnia z 26 czerwca 1974 r.-Kodeks pracy [Act of 26 June 1974-the Labour Code]. Journal of Laws of 2018, item 108.

Ustawa z dnia 13 kwietnia 1998 r. o systemie ubezpieczeń społecznych [Act of 13 April 1998 on the social insurance system]. Journal of laws of 2017, item 1778.

Ustawa z dnia 9 kwietnia 2010 r. o Służbie Więziennej [Act of 9 April 2010 on the Prison Service]. Journal of Laws of 2017, item 631.

Ustawa z dnia 28 maja 2013 r. o zmianie ustawy-Kodeks pracy oraz niektórych innych ustaw [Act of 28 May 2013 amending the Labour Code Act and certain other acts]. Journal of Laws item 675 .

Ustawa z dnia 24 lipca 2015 r. o zmianie ustawy-Kodeks pracy oraz niektórych innych ustaw [Act of 24 July 2015 amending the Labour Code Act and certain other acts]. Journal of Laws item 1220 .

Rozporządzenie Ministra Sprawiedliwości z dnia 18 czerwca 2010 r. w sprawie udzielania zezwoleń na podjęcie zajęcia zarobkowego poza służbą przez funkcjonariuszy Służby Więziennej [Regulation of the Minister of Justice of 18 June 2010 on granting permits to officers seeking gainful employment outside the Prison Service]. Journal of Laws No. 122, item 834.

Rozporządzenie Ministra Rodziny, Pracy i Polityki Społecznej z dnia 8 grudnia 2015 r. w sprawie wniosków dotyczących uprawnień pracowników związanych z rodzicielstwem oraz dokumentów dołączanych do takich wniosków [Regulation of the Minister of Family, Labour and Social Policy of 8 December 2015 on applications concerning the parental rights of employees and the documents accompanying such applications]. Journal of Laws item 2243.

\section{Case Law}

Judgement of the Supreme Administrative Court of 28 October 2008, file ref. no. I OSK 1721/07, LEX no. 499777.

Judgement of the Court of Appeal in Białystok of 18 June 1998, file ref. no. III AUa 296/98, Legalis.

Judgement of the Supreme Administrative Court in Warsaw of 25 March 2011, file ref. no. OSK 2066/10, LEX no. 1079748.

Judgement of the Supreme Court 24 September 2015, file ref. no. II PK 274/14, LEX no. 1962475.

\section{LITERATURE}

BURY, Beata. "Prawo ojca dziecka niebędącego pracownikiem do realizacji uprawnień rodzicielskich związanych z urlopem macierzyńskim.” Monitor Prawa Pracy 5 (2016): 244-49.

Cudowski, Bogusław. Dodatkowe zatrudnienie. Warszawa: Wolters Kluwer Polska, 2007.

Dubownik, Anna. "Dodatkowe zatrudnianie i inne zajęcia pracowników sfery publicznej." Praca i Zabezpieczenie Spoteczne 10 (2005): 15-23.

KaCZOCHA, Mateusz. "Służba Więzienna.” In Komentarz, edited by Marcin Mazuryk and Michał Zoń, LEX 2013/el. 
KuCZYŃSKI, Tadeusz, Eliza MAZURCZAK-JASIŃSKA, and Jakub STELINA. "Stosunek służbowy.” In System Prawa Administracyjnego, edited by Roman Hauser, Zygmunt Niewiadomski, and Andrzej Wróbel, 11: 419: 32. Warszawa: Wydawnictwo C.H. Beck, 2011.

KUMOR-JEZIERSKA, Ewelina. "Dokumentacja w stosunkach zatrudnienia nawiązanych na podstawie ustawy o służbie więziennej." In Dokumenty w zatrudnieniu na podstawie pragmatyk służbowych. Wzory i komentarze, edited by Krzysztof Wojciech Baran, 533-772. Warszawa: Wolters Kluwer Polska, 2015.

Kumor-JeZierska, Ewelina. "Komentarz do rozporządzenia z dnia 8 grudnia 2015 r. w sprawie wniosków dotyczących uprawnień pracowników związanych z rodzicielstwem oraz dokumentów dołączanych do takich wniosków." In Akty wykonawcze prawa pracy. Komentarz, edited by Krzysztof Wojciech Baran, 203-83. Warszawa: Wolters Kluwer Polska, 2016.

Kumor-JeZIERSKA, Ewelina. "Urlop macierzyński funkcjonariuszki Służby Więziennej.” Roczniki Nauk Prawnych 28, no. 1 (2018): 29-51, doi: http://dx.doi.org/10.18290/rnp.2018.28.1-3.

Latos-MıкowsKa, Monika. "Uprawnienia ojców związane z rodzicielstwem." In Aktualne zagadnienia prawa pracy i polityki socjalnej (zbiór studiów), edited by Bolesław M. Ćwiertniak, 2:331-44. Sosnowiec: Oficyna Wydawnicza Humanitas, 2013.

MĘDRALA, Małgorzata. "Wpływ okresu korzystania przez pracownika z obniżonego wymiaru czasu pracy na wymiar urlopu wychowawczego.” Monitor Prawa Pracy 10 (2017): 510-14.

SEKULSKI, Piotr. "Dopuszczalność zatrudnienia w okresie wykorzystania urlopów związanych $\mathrm{z}$ rodzicielstwem." In Uprawnienia pracowników zwiąane z rodzicielstwem w świetle przepisów prawa pracy i ubezpieczeń społecznych, edited by Justyna Czerniak-Swędzioł, 134-56. Warszawa: Wolters Kluwer Polska, 2016.

SoвCZYк, Arkadiusz. Kodeks pracy. Komentarz. Legalis 2017/el.

SOBCZYK, Arkadiusz, and Paweł KoRkus. "Aktywność prywatna i zarobkowa pracownika a urlop wychowawczy." Monitor Prawa Pracy 1 (2014): 24-26.

ŚwiĄTKOwsKi, Andrzej M. Kodeks pracy. Komentarz. Legalis 2016/el.

WiĘCŁAW, Patrycja. "Uprawnienia związane z rodzicielstwem przysługujące osobom prowadzącym własną działalność gospodarczą.” Monitor Prawa Pracy 1 (2018): 20-24.

WŁodARCZyK, Mirosław. Kodeks pracy. Komentarz, edited by Krzysztof Wojciech Baran. Warszawa: Wolters Kluwer Polska, LEX 2016 el.

ZAWIŚLAK, Arkadiusz. "Dopuszczalność pracy u innego pracodawcy w trakcie urlopu wychowawczego—na tle wybranych pragmatyk służbowych.” Monitor Prawa Pracy 9 (2017): 466-71.

\section{THE PARENTAL RIGHTS OF A PRISON SERVICE OFFICER -THE FATHER OF A CHILD}

\section{Summary}

The article describes leave related to childbirth and child raising available to the father of the child who is in a public service relationship with the Polish Prison Service. The child's father has autonomous rights, that is, ones that are only vested in him (paternity leave), and subsidiary rights, which are vested in him but only in a situation where the child's mother does not exercise them (maternity leave), and equivalent rights, that is, those which he can exercise on equal terms with the child's mother (leave on the terms of maternity leave, parental leave, childcare leave). Cases in which a child's parents work in different employment settings are analysed. In this con- 
nection, the author discusses regulations concerning cases of parental leave in situations where the mother and father of a child have the status of PS officers, where the father of a child is a PS officer and the child's mother is employed or covered by social insurance in case of sickness and maternity, specified in the Act of 13 October 1998 on the social insurance system, under a title other than an employment relationship, for example when she is self-employed, and finally cases where a child's mother is not covered by sickness insurance at all.

Keywords: father raising child; paternity leave; maternity leave; parental leave; protection of public service relationship; autonomous rights; subsidiary entitlements; equivalent rights.

Translated by Tomasz Pałkowski

The preparation of the English version of Roczniki Nauk Prawnych (Annals of Iuridical Sciences) and its publication in electronic databases was financed under contract no. 836/PDUN/2018 from the resources of the Minister of Science and Higher Education for the popularization of science. 